\title{
C. Howard Tripp and Brewery Management: The \\ Emergence of Service Sector Management 1850-1914
}

Dr Alistair Mutch

Professor of Information and Learning, Nottingham Trent University

Department of Information Management and Systems, Burton Street, Nottingham,

NG1 4BU

Telephone: 01158482429

Fax: $\quad 01158486512$

Email:_ alistair.mutch@ntu.ac.uk 


\section{Howard Tripp and Brewery Management: The Emergence of Service Sector Management 1850-1914}

\section{Introduction}

1892 saw the publication of Brewery Management by C. Howard Tripp. ${ }^{1}$ This was the first book in the sector to address problems of management, as opposed to the technical problems of brewing. As the Brewers Journal commented 'the rising generation of brewers now devote so much time to the study of chemistry and physiology that there is some risk of their overlooking the fact that the business has to be carried on with the objective of making profits in the face of an ever-increasing competition.' ${ }^{2}$ Part of that 'ever-increasing competition' expressed itself in the form of the growing involvement of brewing companies in the retailing of beer, with the widespread use of the 'tied house' to secure sales. ${ }^{3}$ This article explores this trend as reflected in Tripp's book, with particular emphasis on the development of the direct management of public houses and the absence of this in the work. Tripp's book, then, can tell us something about the growth of management knowledge in this sector, correcting the tendency to focus on manufacturing when exploring the roots of management. ${ }^{4}$ It suggests to us that there was innovation in management practice before the major shift to public limited status in the 1890 s. $^{5}$ However, an examination of Tripp’s account also indicates some of the barriers to the spread of management practices and here we draw upon institutionalist perspectives. These perspectives are rehearsed briefly in William Roy's discussion of the rise of the American industrial 
corporation. ${ }^{6}$ Noting that Chandler's discussion of the growth of management places a heavy emphasis on the technical demands of railroad operation, he argues that this causes him to downplay the influence of existing models of organisation. In this case the model was that of military organisation, and Roy argues that this was a powerful source of ideas. In this, he is following the arguments of Powell and DiMaggio, who argue that companies come to resemble each other not only, or even mainly, because of efficiency considerations, but because they adhere to what is considered legitimate in their sphere of operations. ${ }^{7}$ Such an account demands that we pay careful attention to the structural and cultural influences on management practices. In this case, some attention will be paid to the possible influence of ideas drawn from agricultural practice, and the influence of these on Tripp’s work will be an important sub-theme. Initially, however, we present some brief details of Tripp’s own career in brewery management, in order to place his work in biographical context.

\section{Success and failure in management: C. Howard Tripp 1883-} 1913

The son of a Somerset clergyman, C. Howard Tripp was apprenticed to a brewer at Bedminster before spells at breweries in Stogumber, Tewkesbury and Wiltshire. ${ }^{8}$ In this regard, therefore, he followed a traditional pattern of learning in the industry, focussed as it was on experiential learning dominated by brewing. ${ }^{9}$ His management activities are first recorded in any detail when he moved to the Tadcaster Tower Brewery as general manager in 1883 . His administrative talents were badly needed here. The brewery was owned and 'managed' by three sons of titled gentleman and 
was locally known as the 'snobs' brewery' ${ }^{10}$ Communication between the new manager and the partners was via the medium of a partnership diary. As Avis records

It was Tripp's vehicle for keeping the partners informed of his activities and obtaining their written approval of his actions, and their means of giving him instructions. There were no regular periodic meetings between them and their manager, nor were there any regular meetings between themselves ${ }^{11}$

It is thanks to this diary that Avis is able to give us some details of management practice under Tripp’s charge. He began a process of regular financial appraisal, especially of new projects. There was particular emphasis on the seeking out of new sales leads. Each six months a summary of sales with a commentary on the comparison with previous figures was placed in the diary. ${ }^{12}$ From 1887 Tripp took over all administration. Prior to that date, much of the partners' activity had been in the visiting of the company's public houses; Avis notes that

As trade built up, premises were acquired for use as depots and the change from agent to manager was effected; free public houses were bought to bolster the free trade by a tied presence; then all the agents were gradually replaced by free-trade travellers and tied trade inspectors. ${ }^{13}$

This direct experience of a shift from direct personal involvement to a more structured bureaucratic form of management was to be reflected in one of Tripp’s key concerns in Brewery Management, the management of tied trade. Tripp’s published work actually began with an article on tied house agreements in the Brewers Journal in 
1884, when he was still at Tadcaster. ${ }^{14}$ A year after the publication of his book he took up the post of general manager with Ind Coope in Birmingham. ${ }^{15}$ In the same year he became a director of the British Pure Yeast Company in Burton on Trent, a connection which he was to retain until his death. ${ }^{16}$

At Ind Coope he placed particular emphasis on contracts with the Army, winning a contract in 1894 to supply beer to 9000 troops in India. ${ }^{17}$ He continued to consolidate his place in the industry, becoming the President of the Midland Counties Institute of Brewing in 1894 and, in 1895 the joint managing director of Ind Coope, with a seat on the board. ${ }^{18}$ (It is worth noting that one of the first papers read at the Institute was one on 'Brewery Management’ by L. B. Burdass; later sessions were dominated by technical matters). ${ }^{19}$ Tripp’s activities and publications now became much more concerned with trade policy. In 1903, for example, he published articles on the taxation of beer and contributed to the debate on the compensation of brewers for closed outlets with a piece in the National Review. ${ }^{20}$ This activity brought him considerable praise from the trade press, but performance in his own company was poor. In 1906 Ind Coope passed its dividend. Whilst Tripp was praised for winning overseas business, the real problems were in the home trade, where a decline in sales generally had left exposed those companies which had overspent in their drive to acquire tied houses. It was noted that

Owing to the great trade depression it had been found difficult in some districts to let houses to responsible tenants, and the company had had to undertake the management of several licensed houses, which accounted for the item in the balance sheet of "loss on houses under management". ${ }^{21}$ 
This commentary will prove to be of some significance in assessing Tripp’s published work later. As part of the response to these continuing difficulties Tripp in 1907 took charge of both of the company's breweries in Burton and London, but the problems continued. ${ }^{22}$ In the following year he passed on a salary increase and stated that he would give up $£ 1000$ a year in any year that a preference dividend was not paid. ${ }^{23}$ However, such personal sacrifice was not enough and in 1909 the company was reconstructed. ${ }^{24}$ Tripp remained as joint manager and had the confidence of the trade press, but the inside story was a little different. Tripp left Ind Coope in 1913, with the Brewers Journal noting that the resignation 'has caused general regret in trade circles' but feeling sure he would soon secure an appropriate position. ${ }^{25}$ However, the directors' minutes clearly indicate dissatisfaction with Tripp. When taking him on as joint manager of the further reconstructed Ind Coope in 1912, the minutes note

that such Agreement should be capable of determination by the Board at any time if, owing to any breach or failure to work harmoniously, which may occur between Mr Tripp and the Managing Director, and which cannot be adjusted to the satisfaction of the Managing Director, or if from any other cause whatever and without being called upon to give any reason the Board think it desirable to terminate Mr Tripp's engagement they may do so by giving him one month's notice of their intention and paying him $£ 1500$ to be abated in proportion as the time expires in full compensation of any claims for future salary, or otherwise howsoever. ${ }^{26}$ 
Such conditions indicate that the directors were not as convinced of Tripp’s abilities as were the trade press. Disputes very soon occurred over the level of Tripp’s expenses and 'On Monday, May 26 $6^{\text {th }}$ [1913], the Chairman accompanied by $\mathrm{Mr}$ Malcolmson and Mr Kingsmill interviewed Mr Tripp, when the Chairman with the approval of the whole Board, requested Mr Tripp to resign, which he did and his resignation was accepted. ${ }^{27}$ Tripp went on to carry out some work for Allsopps, particularly in relation to military contracts, but even here there were doubters, with 'Mr Gates and Mr Remnant [expressing] their disapproval of any arrangement with Mr Tripp. ${ }^{28}$ This arrangement was in turn terminated in 1914, and Tripp’s connection with the trade was severed. However, he maintained his interest in the British Pure Yeast Company, still being a director at his death in $1929 .{ }^{29}$ What these biographical details indicate are some of the practical context to Tripp’s writing on brewery management. This context will be useful in assessing the nature of his advice and in giving us further insight into the nature of management in this period.

\section{Brewery Management}

It is important to note that Brewery Management was first published as a series of articles in the Brewers Journal, as this gives us some indications as to timing and content. As we have seen, the first of his articles, which was concerned with tied house agreements, was published in 1884 as he joined the Tadcaster brewery. ${ }^{30}$ This indicates a developing concern with the operation of tied houses that was to influence the contents of Brewery Management. Further articles appeared on brewers' travellers in 1885 and 1889, and revised guidance on house agreements appeared in $1889 .{ }^{31}$ Interestingly, the latter includes a passing mention of managed houses, the 
significance of which will be raised in our later discussion. By 1889 Tripp’s work was being recommended to correspondents in the Brewers Journal's regular questions and answers column, a precursor to the journal's publication of an extended series of articles by him. ${ }^{32}$ The first of these articles, with a focus on malting, appeared in July 1889. A further five articles appeared in 1889, with seven in the following year, concluding with the cellaring of wine in December. Articles on mineral water bottling and management followed in 1891. During this process a letter was published from Arthur Young of Greenwich urging the publication of the articles in book form, and this duly appeared in $1892 .{ }^{33}$ What is important about this process is that the formation of the ideas was underway at the beginning of the 1880s, suggesting that the management practice reviewed had emerged before this date. An account which ties management practice to the publication of books on that practice is in danger of misdating origins, as opposed to dissemination.

Brewery Management in book form was a reproduction of the articles, down to the somewhat unstructured nature of the discussion. An early passage gives something of the flavour of the treatment:

Farmers, whose barley we buy, especially if they are large farmers, are often secured as customers for grains, taking a constant supply all the year round for their cows and pigs; and in the management of a brewery the disposal of grains at remunerative prices is often a very anxious subject, especially during the summer months, when keep and grass are plentiful; although the drying of grains - a subject to which I direct attention later on - will, it is hoped, minimize this difficulty. ${ }^{34}$ 
There is almost a steam of consciousness quality to this passage, starting as it does with the inputs to the brewing process. This impression is strengthened by the beginning of the next paragraph: 'Now, with regard to the actual management of the malt-houses... ${ }^{35}$ Further examples of this rather unstructured approach can be given, but what is also of interest is the emphasis on farming. Of course, the two activities have always been deeply intertwined, but the care lavished on topics such as the keeping of horses is an indication of the deeply rural and agrarian cast of mind that influenced at least this brewery manager. As he argues 'There is another matter in the brewery closely connected with the management to which I would refer before turning attention to the office and other details that we have before us, and that is the horse-keep’. ${ }^{36}$ Again, this is indicative of the extremely unstructured way in which the topic is approached. What, then, does Tripp have to say about management?

Not surprisingly, given his early formation and the types of breweries in which he had worked, Tripp emphasised the primacy of the brewer:

In the management of the brewery it must, of course, be the foremost duty and object of the manager to aid the brewer in every possible way in the multifarious details of his calling, and as the manager would doubtless be well versed himself in practical brewing, it cannot but be of material advantage for the one to have the assistance of the other, where the business is of such size that a manager and brewer each holds a separate appointment. ${ }^{37}$ 
He suggests that under the manager's control should come five departments: cash; ordering and forwarding; ledger; cask; and the manager's department. The latter is concerned in part with general administrative duties such as letter opening, but the over-whelming focus is on dealing with the tied trade, it being 'generally his province to interview the tenants re houses, to hear their complaints re repairs alterations, \&c., and to arrange with the new tenants when changes of tenancy occur, and also assist the solicitors before the magistrates in those cases where the tenants, through any cause whatever, bring themselves within the pale of the law ${ }^{38} \mathrm{He}$ suggests something of a rudimentary structure to deal with these tasks. A clerk might assist in larger breweries, and the cashier might act as deputy, but there is remarkably little consideration in here of a managerial hierarchy or departmental organisation. His words are clearly aimed at the very many small, chiefly rural, breweries which would have no need of such elaborations as separate departments for dealing with the retail trade. They might value advice on how to deal with operational issues in other areas of the business and this is what Tripp offers. Of course this raises questions about how representative of practice Tripp's book is and when we look elsewhere in the industry we can find other examples of practice. However, before turning to them, it is important to also recognise the influence of politics on the industry, how this is reflected in Tripp’s account and how this might condition the growth of management practices.

Tripp is quite clear about this pressure. 'It is obvious,' he writes, 'that the teetotal party during the past two years have been sedulously working to make the question of tied houses a prominent plank in their platform. ${ }^{39}$ In doing so, he argues, they have misrepresented the nature of the tied trade, making it even more important that 
'brewers and all who have the interest of the trade at heart should lose no time in explaining what is meant by a "tied house". ${ }^{40}$ In particular, they would have to clear up the confusion between tied tenant and manager. Whilst there was no evidence that the 'managerial system' was illegal, and whilst it was restricted in its use to limited parts of the country, the impact of this pressure was, he argued, that 'we are, virtually, at the mercy of our tenants'. ${ }^{41}$ Their actions might determine the future of the licence and so it was necessary to ensure that they were 'men of undoubted character and if possible, of position. ${ }^{42}$ Hence the close attention paid to the nature of tenancy agreements and to the importance of the manager taking a personal role in their selection. Such a process did, indeed, seem to characterise the practice of many breweries as indicated in much later accounts. ${ }^{43}$ However, there were other parts of the country in which developments in retailing and concomitant changes in management practices were at a different stage of development. This was reflected in particular in the employment of managed houses as a central part of business strategy, and it to these we turn next as a form of counterpart to Tripp’s discussion.

\section{Managed houses and management hierarchies}

In 1897 Henry Haggis, hotel broker of Manchester, gave evidence to the 'Peel' Royal Commission on the Licensing Laws. He had, he said, been 'outdoor manager' for a local brewery for three years. During this time 'I managed the brewery outside as regards all the letting of the houses and putting the different managers into them and where there was a tenant retiring finding another for them. ${ }^{44}$ What this suggests is a role not covered by Tripp, that of the outdoor manager. In Haggis's case he had been responsible for both managed and tenanted houses. Indeed his evidence indicates the 
prevalence of managed houses in Manchester at a time when the practice was thought to be largely confined to Liverpool and Birmingham. ${ }^{45}$ Others might have just dealt with tenants, but the creation of a separate department was not uncommon. The witness who gave evidence before Haggis, Charles Parker of Barnsley, had been ‘outside manager’ of Clarksons’ brewery prior to $1891 .^{46}$ Allsopp’s London agency ran an 'outdoor department' in $1887 .{ }^{47}$ However, it was in Liverpool, the home of the managed house system, that such departments were at their most developed.

Liverpool from the 1880s was characterised by both an increasing concentration of brewery owned houses and the running of those houses by directly employed managers. ${ }^{48}$ In such an environment there is evidence of the dedication of a specific department to the running of these houses either responsible to a general manager or to the directors. ${ }^{49}$ What is less easy to ascertain is the structuring and operation of these departments. The extant records give us tantalising glimpses, but the records that would enable us, for example, to reconstruct departmental hierarchies have not survived. What the existing records indicate is that these departments were built around strict discipline, designed to impress the police whose practices they to some extent built upon. Peter Walker \& Son thus had house 'inspectors’ at the lowest level. Their job was 'to go into the houses at all times of the day, and at times of the night' and to satisfy themselves that the strict rules for the conduct of houses were being adhered to. ${ }^{50}$ There is a suggestion that they were recruited from the ranks of house managers, the company secretary saying that 'They have been brought up, in the first place, as managers themselves'. John Wells of Warrington, who died in 1915, had served the company for 47 years 'first as a Vaults Manager and latterly as Outdoor Manager ${ }^{51}$ The language of the police is continued in noting that Wells finally 
reached the rank of 'outdoor superintendent', suggesting a role controlling a number of house inspectors. Above these men seemed to be a number of assistant outdoor managers, notably Peter Edge and Frank Calder. At his death in 1902 Edge is recorded as having a 40 year association with the company. ${ }^{52}$ His name can be found in the 1881 licensing registers as holding the licence of 21 London Road. ${ }^{53}$ This was probably as a temporary measure whilst a new manager was sought. In 1901, for example, the premises at 33 Renshaw Street were being subject to extensive renovation. Edge was granted the licence but the 'Police [were] to note that when this house is reopened Mr Edge is not to remain licensee as his occupation precludes him from giving the necessary time to the house' ${ }^{54}$ Frank Calder succeeded William James as Outdoor Manager in 1907, having been with the company for 30 years. Of note here is that he was recorded as being one of the first adherents of New Brighton Presbyterian Church. ${ }^{55}$ Peter Edge was a member of Pitt Street Wesleyan Chapel 'for many years'; perhaps this common base in nonconformity indicates something of the recruitment criteria for such positions? ${ }^{56}$ We know rather less about the man who Frank Calder replaced in overall charge of the outdoor department, William James. Again, when he retired through ill-health in 1907 he had served the company for over 40 years and he was certainly in control of the managed house department in $1896 .^{57}$ In that year he reported to the General Manager, Peter Wright. Wright himself was trusted enough to be named as a beneficiary in Andrew Barclay Walker's will of 1883. ${ }^{58}$ At this stage he was managing the company’s interests in Birkenhead, reporting to the then General Manager, John Price. It is possible, then, to trace the outlines of a managerial hierarchy in a company operating a defined department concerned with retail issues at the same time that Tripp was writing Brewery Management; what of its operation? 
Again, the records do not permit us to explore operations in detail. One comment of Ellis's, though, is suggestive. The house manager was to take his own wages and those of the staff out of the cash takings. He was also to pay for supplies not received directly from the brewery and then 'every week he hands over the balance, keeping an account of what he has received and paid, to the head office on the Monday morning' ${ }^{59}$ He was to order trade goods on a printed slip returned to head office. What this suggests is that the house inspectors were not involved in the business running of the house, apart from making sure that procedures were followed. The company engaged in detailed accounting, keeping accounts for each house and taking stock fortnightly. These accounts were certainly used between 1850 and 1879 to draw up an annual profit and loss account for each house. ${ }^{60}$ These practices relate to the form of the company as, firstly, an informal partnership between Andrew Barclay Walker and his father Peter between 1846 and 1879, and then a more formal partnership until the company was floated in 1890. Andrew Walker died in 1893 and his sons took over the running of the company. Unfortunately there is a gap in the minute books until 1898; by this stage the level of monitoring appears to have been at a very high level. 'Vault receipts' are noted at each meeting, but with little attempt at analysis. ${ }^{61}$ However, what we might suggest is that there existed a 'system' for running retail outlets, one that, in the crusading words of the company, 'offers opportunity for regulating and systematising a business that demands scrupulous care and attention not only to details, but to broad popular demands. ${ }^{62}$ There is the hint in that last phrase of an orientation towards customers that was not at all common in the industry. Very much later, the representative of another company which also adopted 
the 'managerial system', Arthur Mitchell of the Birmingham firm Mitchells and Butlers was to argue that

I have heard it said that customers of licensed houses liked the small, inconvenient, hole-and-corner places of the past. In my experience of the licensed trade, and having been in close touch with our customers through the company's managerial system of trading, I can honestly say this is all stuff and nonsense ${ }^{63}$

However, this focus on direct retail trading was slow to emerge, and this was partly because of the orientation on production and on public houses as distribution outlets that characterises Tripp’s work. Again, it is interesting here to note Avis's assessment of the major London brewers Charrington in the late 1950s:

The brewery policy over the years had developed into one of selling their beer only to their own tenants, ignoring the attractions of free trade customers and the retail profits of managed public houses, both being rather too close to the reality of the beer trade. The company structure had been converted into an organisation for collecting rents ${ }^{64}$

These are, of course, much later examples than the main focus of our work but they are helpful in putting Tripp’s work into context. That context is one in which the very title Brewery Management is suggestive of a particular focus. It shows in the subsequent use of managers by Ind Coope, as we have seen above, not as a key part of 
business strategy but as a stop gap. A similar attitude can be seen in the report in 1905 from Allsopps

Regarding the loss on houses under management, I may remind you that earlier in our management of the company we had something like 61 houses under management., involving an annual loss of some $£ 7,000$ or $£ 8,000$ a year. We have worked these down gradually, and at the time of the closing of these accounts we had only 11; of these, three have since gone out of management, and the loss on the year's working is only $£ 2,000^{65}$

In this case, we might want to relate this report to the prevalence of agency working in Allsopps and other companies. Prior to 1860s these were predominantly independent traders, men of considerable stature like the Liverpool agent Henry Danson, leading light in the local Licensed Victuallers Association. ${ }^{66}$ Such traders might also want to deal in the goods of other brewers, which might cause conflict. ${ }^{67}$ As a result of such conflict Allsopps appear to have brought their major agencies under direct management from the mid-1860s onwards and began the creation of a department charged with their oversight. In $1865 \mathrm{Mr}$ Dilworth was appointed 'to the Management of the Agencies’ and it was resolved

That Mr Auty act as Assistant to Mr Dilworth with a view to acquiring all the Knowledge possessed by Mr Dilworth in the various departments, and that he travel and visit Agencies when Mr Dilworth is able to spare him from Burton. $^{68}$ 
Auty took over as agency manager in 1867 and in the following year it was

Agreed that Mr Auty's book showing the result of his visits to the various Agencies be laid on the table each week, \& that Mr Auty attend to give any further explanation respecting same which may be required. ${ }^{69}$

Auty was to become a director in 1889 , which seems to suggest that the position was one of some status. ${ }^{70}$ However, what we retain is the language of 'agency' which a suggestion that the direct control of retail activities was limited. The degree of control might be indicated by the decision to appoint Robert Riddell as 'Assistant Inspector of Agencies' to help Auty in $1891 .^{71}$ Given the scale of business and the spread of agencies across the country, this seems to suggest a limited degree of contact. There is little evidence here of a hierarchy of staff, and no reporting of performance to the board, although unfortunately the records are not sufficiently detailed to be able to be more definite. What the Allsopps example does seem to suggest, however, is that there was the growth of a managerial hierarchy to deal with non-brewing affairs in the mid-nineteenth century, but that this growth was attenuated. It was limited by an adherence to both a production perspective and to the agency model. With this in mind, we can return to an assessment of the place of Tripp's work in the development of management.

\section{Conclusion}

Tripp’s work on brewery management is interesting for a number of reasons. We have seen that it is far from representative of all management practices within the industry. 
However, its very existence suggests that such practices were becoming a matter of some concern. It offers us a 'way in' to a range of practices. The most interesting thing about these practices from the point of view of the general history of management is their date. A range of practices, from those in small rural breweries with their rudimentary structures, to great national brewers with their reliance on agents, to the regional brewers of Liverpool and Birmingham with their welldeveloped managerial systems indicate how much work was being carried out from the 1860s onwards. Clearly, more work would be useful here (although we have to be mindful of the limits of the archival record) but that which has been presented provides some support for those, such as Church, who suggest that a focus on the developments of the 1890s is misleading. This focus on the 1890 s and manufacturing/engineering, as in Shenhav's excellent discussion, can be misleading. Some histories of brewing succumb to the temptation to see the public floatations of the 1890s as marking a distinctive break, in that they bring about the application of 'commercial' practices. ${ }^{72}$ Such accounts both tend to exaggerate the extent of these changes, telescoping for example shifts towards a retailing orientation that properly belong to the 1950 s, and to ignore what had gone on before. ${ }^{73}$

What is important about Tripp is not just what he might tell us about aspects of these earlier practices, but also the way in which he frames the debate. With the exception of more specialised works on accounting practice within brewing, Tripp’s work is virtually the only consideration of managerial practice in the industry until a series run by the Brewers Journal in $1934 .^{74}$ The exception to this is the work on retailing which we will consider shortly. However, it is interesting to note the continued absence of even the limited forms of systematic organisation called for by Tripp, let 
alone those put into practice by the likes of Peter Walker \& Son and Mitchells and Butler. ${ }^{75}$ If we can once again trespass beyond the limits of our period, we can get an indication of this absence of system even in urban brewers by recording Avis's strictures on Offiler’s Brewery of Derby in the 1960s. Run by two cousins, descendants of the founder, 'it was,' Avis recalls, 'one of the sleepiest brewery companies I had so far experienced, even in an era of comatose management. ${ }^{76}$ The extent to which the combined efforts of Tripp and the Brewers Journal had passed it by can be seen in Avis’s despairing conclusion that 'it was feudal, dormant, and without any energy, sense of purpose, or direction. It was difficult to get figures or lists, or worthwhile information; not because there was obstruction, but the data, in modern jargon, was not assembled. ${ }^{77}$ It is interesting to note here the constraints on the diffusion of knowledge which seem to be expressed in the evidence given by Thomas Down, managing director of Greenall Whitley, to the Peel Commission. Speaking immediately after Ellis had given his exposition of Peter Walker and Son's system of house management, he commented that 'I know nothing of the managerial system, but I believe the houses of Messrs. Walker in Warrington are as well conducted as they can be, and they are mostly under management' ${ }^{78}$ Given that his company operated in part out of Warrington, the location of Peter Walker \& Son's brewery and that they also operated Liverpool public houses, this is a remarkable statement that attests to the fragmented and closed nature of the industry. On the publication of Burdass's discussion of brewery management in 1894 the Brewers Journal commented that 'he gives us some remarkably useful practical hints, in an open and generous manner almost foreign to British traders. ${ }^{79}$ This indicates one constraint on the diffusion of practices but we also have to consider a lack of interest 
in these topics which might be seen in the general question of how the nature of retailing was viewed in the industry.

In 1923 Alexander Part, former managing director of Trust Houses Limited (and from 1924 head of Barclay Perkins ‘improved public house’ department), observed ‘the fact is that there is no natural affinity between Brewing and Hotelkeeping ; the alliance is entirely "a marriage of convenience”, and the best remedy, in practice, is divorce. ${ }^{80}$ He was referring to the reluctance with which many brewery companies had taken on the ownership of public houses and ran them as if they were simply distribution outlets. We have already seen that this was the dominant theme in Tripp’s work. Immediately before the First World War, Sydney Nevile of Whitbread had attempted to raise the issue of retailing and training. In 1912 he ran a course of six lectures on 'The Retail Management of Beverages' at the Sir John Cass institute in London. ${ }^{81}$ In discussing these efforts at the Institute of Brewing he recognised the limited scope of these efforts and argued that 'it should eventually include the handling of refreshments, elementary law, some knowledge of accounts, and the many other matters which touched the licensed trade. ${ }^{82}$ However, these discussions indicate the limited extent to which many companies had adopted any form of retailing orientation. One member of his audience touched on some of the institutional and structural factors behind this when he noted the opposition of London magistrates to public house managers. 'If the London brewers', he argued, 'were in the same position as some of the brewers in the North of England - their managers being their servants - then they could dictate as to what should be done. ${ }^{83}$ This reminds us of the political context in which brewers operated and which shaped some of their responses. In Liverpool and Birmingham the magistrates and other local state 
agencies supported the notion of house management, but in a form which reinforced the disciplinary, as opposed to the retailing aspects of the system. ${ }^{84}$

The managerial system, of course, was not the only form which such a retailing orientation could take. However, it would seem that other factors reinforced the dominant focus of brewers on production. One might have been the way in which for Tripp the process and management of brewing was tightly bound up with rural and agricultural themes. Of course, the very process of brewing was tightly bound up with the sourcing and processing of agricultural products, but the connections seem to go further. The adherence to the tenancy model and the nomenclature of the agency seems to mirror the language of the rural model of landed estates farmed by independent tenants answerable to land agents. Such a model, in which the emphasis is placed on the autonomy of the tenant, is a key concern of mid-Victorian writing on agricultural practice, which spilled over into the pages of the business press, rudimentary as it was. The Economist, for example, ran frequent articles on the advantages of tenants in the 1860s, articles which also extolled the virtues of independent and skilful agents. ${ }^{85}$ A further exploration of these connections would be valuable, but in such an environment, which leading brewers would also be mimicking on their own country estates, it is perhaps hardly surprising that a leading brewer like Samuel Whitbread could argue in Parliament in 1872 that the London system in which independent property owners borrowed from brewers was 'the most healthy form of trade' ${ }^{86}$ The emphasis here was on the independence guaranteed by a substantial stake in the business. In such an arrangement, the brewer could remain distant from the concerns of the retail trade. Such attitudes were carried over into the much expanded retail estates of the brewers from the 1880s onwards. Even though the 
independence of tenants might be only nominal, they were not the 'mere servants' that managers were portrayed as. Such attitudes meant that managerial hierarchies were rudimentary and that their main attention was focussed on rent collection rather than on the nature of the market in which they were operating. Tripp’s Brewery Management did little to disturb such views. Whilst it indicates that there was development in management practice before the 1890s, it also is part of the reason why changes that had happened far earlier were not generalised throughout the industry. The development and diffusion of management thought and practices is therefore a complex process influenced as much by cultural and institutional factors as by purely economic ones.

\footnotetext{
${ }^{1}$ C Howard Tripp, Brewery Management, 1892, F W Lyon, London.

${ }^{2}$ Brewers Journal (BJ), 15 June 1892, p. 284.

${ }^{3}$ T. R. Gourvish and R. G. Wilson, The British Brewing Industry 1830-1980, Cambridge UP, 1994

${ }^{4}$ Yehouda Shenhav, Manufacturing Rationality, Oxford UP, 1999

${ }^{5}$ Roy Church, 'Ossified or dynamic?' Business History, 2000, 42, 1, pp. 1-20.

${ }^{6}$ William G Roy, Socializing Capital The Rise of the Large Industrial Corporation in America, Princeton UP, 1997.

${ }^{7}$ Walter W Powell and Paul J DiMaggio, The New Institutionalism in Organizational Analysis, University of Chicago, 1991.

${ }^{8}$ BJ, 15 June 1913, p. 344.

${ }^{9}$ Jonathan Reinarz, 'Fit for Management: Appreticeship and the English Brewing Industry, 1870-1914, Business History, 43(3), pp. 33-53.

${ }^{10}$ Will Swales, The History of the Tower Brewery Tadcaster, Bass Brewers, Burton, 1991; Anthony Avis, The Brewer's Tale: A History of Ale in Yorkshire, Radcliffe Press, London, 1995.

${ }^{11}$ Avis, Brewer's Tale, p. 3.

${ }^{12}$ Avis, Brewer's Tale, p. 159.

${ }^{13}$ Avis, Brewer's Tale, p. 22.

${ }^{14}$ C. Howard Tripp, 'Tied Houses and Brewers' Agreements’, BJ, 15 Feb. 1884, pp. 70-71.
} 
${ }^{15}$ BJ, 15 Dec. 1893, p.641.

${ }^{16}$ BJ, 15 Nov. 1893, p. 522; he became chairman in 1896: BJ, 15 Nov. 1896, p. 367.

17 'Beer for Egypt', BJ, 15 June 1894, p.302.

${ }^{18}$ BJ, 15 Nov. 1894, 597; BJ, 15 June 1913, p. 344.

19 'Brewery Management, BJ, 15 May 1894, pp. 238-9.

${ }^{20}$ C. H. Tripp, ‘The Taxation of Beer’, BJ, 15 Jan. 1903, pp. 43-4; ‘The Sources of Compensation’, BJ, 15 July 1903, pp. 371-3.

21 'Ind Coope and Co', BJ, 15 Feb. 1906, p. 217

${ }^{22}$ BJ, 15 Feb. 1907, p. 132.

${ }^{23}$ BJ, 15 Apr. 1908, p. 259.

${ }^{24} L V G, 10$ Dec. 1909, p. 9.

${ }^{25}$ BJ, 15 June 1913, p. 344.

${ }^{26}$ National Museum of Brewing (NMB) Burton, Ind Coope (1912) Minutes book 115 Oct 1912-26 July 1920, 10 Feb. 1913.

${ }^{27}$ NMB Ind Coope (1912) Minutes book 1, 2 June 1913.

${ }^{28}$ NMB Allsopps minute books, Book 9 August 1913 - Sep 1916, 4 Aug. 1914.

${ }^{29}$ BJ, 15 Dec. 1929, p. 611.

${ }^{30}$ C. Howard Tripp, Tied Houses and Brewers' Agreements., BJ, 15 Feb. 1884, pp. 70-1.

${ }^{31}$ C. Howard Tripp, 'Brewers' Travellers', BJ, 15 July 1885, pp. 265-9; C. Howard Tripp, 'Brewers'

Travellers', BJ, 15 Feb. 1889, pp. 99-103; C. Howard Tripp, Brewers' Agreements and Tied Houses, BJ, 15 April 1889 pp. 213-17 and 15 May 1889 pp. 280-2.

${ }^{32}$ BJ, 15 Jan. 1889, p. 50.

${ }^{33}$ BJ, 15 Nov. 1889, pp. 613-4.

${ }^{34}$ Tripp, Brewery Management, p. 2.

${ }^{35}$ Tripp, Brewery Management, p. 2.

${ }^{36}$ Tripp, Brewery Management, p. 23.

${ }^{37}$ Tripp, Brewery Management, p.14.

${ }^{38}$ C. H. Tripp, BJ, 15 Nov. 1889, pp. 600-1

${ }^{39}$ Tripp, Brewery Management, p.94.

${ }^{40}$ Tripp, Brewery Management, p.94. 
${ }^{41}$ Tripp, Brewery Management, p.138

${ }^{42}$ Tripp, Brewery Management, p.94.

${ }^{43}$ Tom Berkeley, We Keep a Pub, Hutchinson, 1955; Tim Wilkinson, We Ran a Cornish Pub, 1967

${ }^{44}$ Royal Commission on the Licensing Laws, Second Volume of Evidence (P.P. 1897, XXXV), p. 441.

${ }^{45}$ A. Mutch, Manchester and Liverpool Public Houses Compared 1840-1914', Manchester Region

History Review, 16, (2003), 22-29

${ }^{46}$ RC Licensing (2), p. 436

${ }^{47}$ NMB, Allsopps, Directors Minute Books, Book 1b,Feb 1887 - Oct 1890, 1 Nov. 1887.

${ }^{48}$ A. Mutch, 'Magistrates And Public House Managers 1840-1914: Another Case Of Liverpool

Exceptionalism?’ Northern History, 40(2), (2003), pp. 325-342.

${ }^{49}$ Robert Cain \& Sons: L(iverpool) R(ecord) O(ffice) 380PWK 18/1/2 Minute book of Robert Cain and Sons 30 Nov. 1908; Peter Walker \& Son: PP C-8693 1898 XXXVI Third volume of evidence evidence of Ernest Ellis, secretary, p. 393; Robert Blezard: Liverpool Courier, 4 Jan 1907; James Mellor: 'The Managerial System', BJ, 15 Apr. 1914, p. 218; Rowland Bent \& Co: B. Guiness Orchard, Liverpool's Legion of Honour, The Author, 72 Bridge St, Birkenhead, 1893, p. 618; Peter Walker \& Company: NMB, BNMB95.2731.00, Peter Walker \& Company board minute book 1907-1911, 27 Apr. 1908.

${ }^{50}$ Royal Commission on the Licensing Laws, Third Volume of Evidence (P.P. 1898, XXXVI), p. 393.

${ }^{51}$ LRO 380PWK/3/1/2 Peter Walker \& Son, directors’ minute book 2, 5Oct. 1915.

${ }^{52}$ Liverpool Mercury, 6 Aug. 1902.

${ }^{53}$ LRO 347JUS/1/1/38 1881

${ }^{54}$ LRO 347JUS/ 1/1/53 F-L 33 Renshaw Street, 1901

${ }^{55}$ Liverpool Courier, 11 Nov 1908

${ }^{56}$ Liverpool Mercury, 6 Aug. 1902.

${ }^{57}$ Peter Walker \& Son, Walker's Warrington Ales, Warrington, 1896, p. 53.

${ }^{58}$ Derbyshire Record Office, D1849 Walker-Okeover Papers, Estate of Andrew Barclay Walker, 4 January 1883.

${ }^{59}$ RC Licensing (3), p. 391. This practice continued until direct banking by house managers was instituted in 1920: LRO 380PWK/3/1/3 Minute Book No 3 1916-1928, 2 Nov. 1920.

${ }^{60}$ For more detail, A. Mutch, 'Public houses as multiple retailing: Peter Walker \& Son 1846-1914’, forthcoming 
${ }^{61}$ See for example LRO 380PWK/3/1/2 Minute book of Peter Walker and Sons Ltd, 1 February 1898.

${ }^{62}$ Peter Walker \& Son, Walkers Warrington Ales, p. 56.

${ }^{63}$ 'Replanning Public-Houses - The Fallacy of the Population Test', BJ, 17 Jan. 1945, p. 41.

${ }^{64}$ Anthony Avis, The Brewing Industry 1950-1990: Notes and Reflections 1950-1990, Anthony Avis, Ilkley, 1997, p. 97.

65 'Samuel Allsopp and Sons, Limited', BJ, 15 Sept. 1905, p. 549.

${ }^{66}$ Liverpool Courier, 25 September 1885.

${ }^{67}$ In 1866 it was 'Agreed that Mr Forster be informed that the House passed a Resolution in April last objecting to the Sale of Porter by their Agents for other firms and regret therefore they cannot comply with his request’: NMB, Allsopp’s directors’ minute book 1a April 1865 - Feb 1887, 13 Nov. 1866.

${ }^{68}$ NMB, Allsopp’s directors' minute book 1a April 1865 - Feb 1887, 11 July, 4 Aug. 1865.

${ }^{69}$ NMB, Allsopp’s directors’ minute book 1a April 1865 - Feb 1887, 10 March 1868, 15 Fe. 1870.

${ }^{70}$ NMB, Allsopp’s directors’ minute book 1b Feb. 1887 - Oct. 1890, 9 Jul 1889

${ }^{71}$ NMB, Allsopp’s directors’ minute book 2, Oct. 1890 - Nov. 1893, 18 Dec. 1891.

${ }^{72}$ For example, T. Collins and W. Vamplew, 'The Pub, the Drinks Trade and the Early Years of Modern Football', The Sports Historian, 20(1), (2000), pp. 5-6 and D. Gutzke, Protecting the Pub: Brewers and Publicans Against Temperance (Boydell Press, Woodbridge, 1989), p. 181.

${ }^{73}$ Problems discussed at greater length in A. Mutch, 'Shaping the public house 1850-1950: business strategies, state regulation and social history' Cultural and Social History, 1(2), (2004), 179-200.

${ }^{74}$ E. g. S. Howard Withey, 'Control of Brewing Materials and Stores', BJ, 15 Jul. 1934, pp. 435-6; W. Harris, A Lecture on Brewers' Accounts, The Paper and Printing Company of Ireland, Dublin, 1892

${ }^{75}$ For M\&B systems see A Mutch, 'Managing Managers: an Early Twentieth Century Service Industry Information System’, Management Decision, 40(3) (2002), pp. 288-96.

${ }^{76}$ Avis, Brewing Industry, p. 79.

${ }^{77}$ Avis, Brewing Industry, p. 80.

${ }^{78}$ RC Licensing (3), p. 409.

79 'Brewery Management', BJ, 15 May 1894, p. 238.

${ }^{80}$ A. F. Part, The Art and Practice of Innkeeping (Heinemann, London, 1922), p.169.

81 'The Retail Management of Beverages', BJ, 15 May 1912, pp. 291-2.

${ }^{82}$ Sydney Nevile, 'Cellar Management', Journal of the Federated Institute of Brewing, 1911, p. 568. 
${ }^{83}$ Nevile, ‘Cellar Management’, p. 558.

${ }^{84}$ A. Mulch, 'Magistrates And Public House Managers'.

85 'Landlord, Land-Agent, and Tenant', The Economist, 22 August 1863, pp. 931-2; ‘ Social Influence and Position of Farmers', The Economist, Sep 19 1863, 1042-3.

${ }^{86}$ House of Commons Debates, 212, 7 August 1872, p. 656.

26 